\title{
Quantitative Genetic Variation in Gum Arabic (Acacia senegal (L) Willd) Provenances
}

\author{
N. M. Fakuta1 ${ }^{*}$, I. F. Ojiekpon1' I. B. Gashua ${ }^{2}$, O. C. Ogunremi ${ }^{3}$ \\ ${ }^{1}$ Rubber Research Institute of Nigeria, Gum Arabic Sub-Station, Gashua, Nigeria \\ ${ }^{2}$ Department of Science Laboratory, Technology Federal Polytechnic, Damaturu, Nigeria \\ ${ }^{3}$ National Biotechnology Development Agency, Abuja, Nigeria \\ Email: 'fakuta1st@gmail.com
}

Received 28 September 2015; accepted 9 November 2015; published 12 November 2015

Copyright (C) 2015 by authors and Scientific Research Publishing Inc.

This work is licensed under the Creative Commons Attribution International License (CC BY).

http://creativecommons.org/licenses/by/4.0/

(c) (i) Open Access

\section{Abstract}

Twelve (12) Acacia senegal provenances were evaluated at the Rubber Research Institute of Nigeria, Gum Arabic Sub-Station Gashua, Yobe state. Gum yield and some morphological data were collect in three years to estimate mean effects, genetic variability, heritability and genetic advance in Acacia senegal provenances. The analysis of variance revealed highly significant difference for all traits. Genetic component analysis showed that both genotypic coefficient of variation (GCV) and phenotypic coefficient of variation (PVC) were high for all the traits except bark thickness. PCV was higher in proportion than GCV with respect to all the traits. Gum yield gave the highest relative difference (RD) over other traits. Heritability estimates were high for bark thickness (77.36) and stem diameter (61.75). Expected genetic advance was high in number of tree incision (1.29), stem diameter (1.54) and yield in $\mathrm{kg} / \mathrm{ha} \mathrm{(22.31).} \mathrm{This} \mathrm{study} \mathrm{indicated} \mathrm{that} \mathrm{there} \mathrm{was} \mathrm{sufficient} \mathrm{ge-}$ netic variability in Acacia senegal provenances that could be used as a base for improvement of yield and other component attributes of this species through direct selection and hybridization.

\section{Keywords}

Gum Arabic, Genotypic Coefficient of Variation, Phenotypic Coefficient of Variation, Genetic Advance, Provenances

\section{Introduction}

Acacia senegal is a leguminous multipurpose African tree species belonging to the family Fabaceae [1]. The

*Corresponding author.

How to cite this paper: Fakuta, N.M., Ojiekpon, I.F., Gashua, I.B. and Ogunremi, O.C. (2015) Quantitative Genetic Variation in Gum Arabic (Acacia senegal (L) Willd) Provenances. American Journal of Plant Sciences, 6, 2826-2831.

http://dx.doi.org/10.4236/ajps.2015.618279 
plant is a deciduous tree up to $12 \mathrm{~m}$ tall with short thorns of less than $1 \mathrm{~cm}$ in length located below the nodes and occurred in sets of three with the middle one curving downward. The leaves are small 3 - 8 pairs of pinnae each with 7 - 25 pairs of leaflets clustered together and pale green in colour [1] [2]. Tapping commences when the trees reach a height of $1.2-1.5 \mathrm{~m}$ with a main stem diameter of about $5 \mathrm{~cm}$ from $5-7$ years of age depending on management practice [3]. The trees are usually tapped from the main stem and branches using a special debarking tool called axe which is used in removing the bark, while taking care not to damage the cambium [4]. Gum yield of about $300 \mathrm{~g} /$ tree/annum is common, however, yield of about $900 \mathrm{~g} /$ tree/annum or 1 ton/ha is possible among older trees [5]. The tree is highly valued for gum Arabic production utilized as a multifunctional food additive, confectioneries, pharmaceuticals, food and beverages, brewing among others [5] [6]. The ultimate goal of Acacia senegal breeding is to improve the species earliness to tapping maturity, gum quantity and quality which largely depend upon the genetic variability, heritability and genetic advance of desirable traits. The magnitude and type of genetic variability help breeders to determine the selection criteria and breeding schemes to be deployed for improvement purposes. This investigation was therefore undertaken to estimate the variability, heritability and genetic advance in twelve (12) Acacia senegal provenances for improvement purposes.

\section{Material and Methods}

\subsection{Germplasm Collection}

Twelve Acacia senegal provenances were collected from two major ecological zones (Sudan and Sahel) with strong evidence of the species in Yobe state, Nigeria in 2006 (Table 1). Collection was specifically made at Yusufari, Jajimaji Bulkati and Usur (Sahelian ecology) and Damaturu, Ngaburwa, Fune and Gujba (Sudan ecology). The selection criteria were based on the provenance trial recommendations of Burley and Wood [7], where provenance nomenclature was standardized using locational details with a minimum interval of 100 meters apart to avoid inclusion of likely half-sibs in the collection. Healthiest pod in the best stage of maturity was selected from 25 trees in each provenance because of heterogeneous nature of the population.

\subsection{Provenance Trial and Design}

The provenance trial was established at the experimental field of the Rubber Research Institute of Nigeria, Gum Arabic Sub-Station, Gashua, located at latitude $12^{\circ} 46^{\prime} \mathrm{N}$, longitude $11^{\circ} 00^{\prime} \mathrm{E}$ and altitude $360 \mathrm{~m}$ above sea level. Seedlings of the twelve (12) Acacia senegal provenances were nurtured in the nursery for four months before transplanting to the field in August, 2008 in a Randomized Complete Block Design (RBCD) with three replications. Each provenance consisted of a square plot with sixteen trees $(4 \times 4)$ row spaced at $3 \mathrm{~m} \times 3 \mathrm{~m}$ [8].

Table 1. Description of twelve Acacia senegal provenances and their geographical locations, Yobe state.

\begin{tabular}{|c|c|c|c|c|c|}
\hline Ecology & Location & Provenance code & Latitude (N) & Longitude (E) & Altitude (M) \\
\hline \multirow[t]{6}{*}{ Sahel } & Yusufari 1 & $\mathrm{P} 1$ & $13^{\circ} 2^{\prime} 6^{\prime \prime}$ & $11^{\circ} 8 ' 44^{\prime \prime}$ & 370 \\
\hline & Yusufari 2 & P2 & $13^{\circ} 2^{\prime \prime \prime}$ & $11^{\circ} 8^{\prime} 37^{\prime \prime}$ & 371 \\
\hline & Yusufari 3 & P3 & $13^{\circ} 1^{\prime} 59^{\prime \prime}$ & $11^{\circ} 9^{\prime} 4^{\prime \prime}$ & 375 \\
\hline & Jajimaji & P4 & $12^{\circ} 53^{\prime} 45^{\prime \prime}$ & $1^{\circ} 52^{\prime} 38^{\prime \prime}$ & 370 \\
\hline & Bulkati & P5 & $12^{\circ} 53^{\prime} 5^{\prime \prime}$ & $1^{\circ} 53^{\prime} 15^{\prime \prime}$ & 364 \\
\hline & Usur & P6 & $12^{\circ} 53^{\prime} 1^{\prime \prime}$ & $1^{\circ} 59 ' 32^{\prime \prime}$ & 360 \\
\hline \multirow[t]{6}{*}{ Sudan } & Damaturu & P7 & $11^{\circ} 41^{\prime} 27^{\prime \prime}$ & $11^{\circ} 56^{\prime} 39^{\prime \prime}$ & 410 \\
\hline & Ngaburwa & P8 & $11^{\circ} 45^{\prime} 34^{\prime \prime}$ & $12^{\circ} 7^{\prime} 56^{\prime \prime}$ & 409 \\
\hline & Fune & P9 & $11^{\circ} 41^{\prime} 43^{\prime \prime}$ & $11^{\circ} 41^{\prime} 46^{\prime \prime}$ & 435 \\
\hline & Gujba1 & $\mathrm{P} 10$ & $11^{\circ} 23^{\prime} 8^{\prime \prime}$ & $11^{\circ} 58^{\circ} 8^{\prime \prime}$ & 450 \\
\hline & Gujba2 & P11 & $11^{\circ} 24^{\prime} 27^{\prime \prime}$ & $11^{\circ} 59^{\prime} 27^{\prime \prime}$ & 431 \\
\hline & Gujba3 & P12 & $11^{\circ} 24^{\prime} 39^{\prime \prime}$ & $11^{\circ} 59^{\prime} 38^{\prime \prime}$ & 456 \\
\hline
\end{tabular}




\subsection{Provenance Evaluation}

Each provenance was exploited for gum yield at four years after establishment using tapping knife to make an incision of $3 \mathrm{~cm} \times 15 \mathrm{~cm}$ [9]. Number of incision was determined by counting the number of tapping cuts. Bark thickness $(\mathrm{cm})$ and stem diameter $(\mathrm{cm})$ were determined by using Venier caliper. Gum yield $(\mathrm{kg} / \mathrm{ha})$ was determined by harvesting the gum and shade drying to $15 \%$ moisture content before weighing on a digital weighing balance (Hecky High Precision). Analysis of morphological traits and gum yield were carried out for three years (2011 to 2013). Each year number of tree incisions, bark thickness and stem diameter were taken at the commencement of tapping while number of gum bearing incisions and gum yield were taken monthly for three month.

\subsection{Data Analysis}

Data collected were subjected to analysis of variance; F-test was used to test for significant differences among the measured traits [10]. Provenance means were compared using Duncan's Multiple Range Test [11]. The data were analyzed using the general linear model procedure of statistics analysis system software version 9.0 [12]. The mean squares were used to estimate phenotypic variance $\left(\sigma_{p}^{2}\right)$ and genotypic variances $\left(\sigma_{g}^{2}\right)$ [13]. The methods of Burton and Devane were used in calculating the genotypic and phenotypic coefficient of variations [14], as: $\operatorname{GCV}(\%)=\sigma_{g}^{2} \times 100 /$ grand mean and PCV $(\%)=\sigma_{p}^{2} \times 100 /$ grand mean. $\left(\sigma_{p}^{2}\right)=$ genetic variance $\left(\sigma_{g}^{2}\right)+$ environment variance $\left(\sigma^{2} e\right)$ by Acquaah (2007). The recommendation of Nechif and co-workers were followed in the determination of Relative difference (RD \%) between PCV (\%) and GCV (\%) $=[100$ (PCV GCV)/PCV [15]. Broad sense heritability $\left(h_{b}^{2}\right)=\sigma_{g}^{2} / \sigma_{p}^{2}$ and genetic advance $(\mathrm{GA})=\Delta \mathrm{S} \times h_{b}^{2} \times \sqrt{\sigma_{p}^{2}}$ were calculated by using the methods adopted by Acquaah and Falconer \& Mackay respectively [16] [17].

\section{Results and Discussion}

\subsection{Mean Effects of Gum Yield and Other Morphological Traits in A. senegal Provenances}

Provenances 11 and 12 though statistically similar, had superior growth traits compared to the rest of the provenances most times except gum yield averaged over 3 years tapping season as presented in Table 2. The highest gum yield was achieved with P9 while the lowest was recorded by P6 and P3. Provenance three (P3) often resulted in significantly lower morphological and yield traits. The superior growth put up by provenances of Gujba origin is not surprising as variability in growth among provenance population of Acacia senegal has been very well documented [18]. Also, the higher gum yield recorded with P9 is in order because Fune vegetation type is reminiscent of sahelian agro-ecological zone. The specie has been reported to put strong growth and yield performance under hash environmental conditions [19].

The analysis of variance result is shown in Table 3. The provenances showed significant differences for all traits measured in the study, indicating the presence of an adequate variability among the provenances for selection and identification of superior genotypes. Year effects were also significant for all traits except bark thickness probably due to yearly differences in weather variables.

\subsection{Genetic Components of Variance, Heritability and Genetic Advance}

As shown earlier in Table 2, the twelve A. senegal provenances showed wide range of variability in most of the traits studied. Tree incisions, number of gum bearing incisions and yield were relatively low. This investigation revealed considerable amount of variations for traits like barks thickness and stem diameter (Table 4). Such wide variations indicate prospects for improvement in these traits. Provenance variations in A. senegal growth traits which include plant height, canopy spread and stem diameter were earlier reported [20].

The phenotypic variance ( $\sigma_{p}^{2}$ ) was slightly higher than the genotypic variance ( $\sigma_{g}^{2}$ ) for all traits except bark thickness that gave the same estimate. However, phenotypic coefficient of variation (PCV) was higher in proportion than genotypic coefficient of variation (GCV) for all the traits suggesting the presence of environmental influence in the expression of these traits. GCV and PCV values greater than $20 \%$ are regarded as high, whereas values less than $10 \%$ are considered to be low [21]. Also, values between 10 and $20 \%$ are considered to be moderate. High GCV and PCV values were recorded for number of tree incision, stem diameter and gum yield while GCV was moderate and PCV high for number of gum bearing incision. These offer a wide range of 
Table 2. Mean effects of gum yield and other morphological traits in A. senegal provenances evaluated across 3 years in Gashua.

\begin{tabular}{|c|c|c|c|c|c|}
\hline Provenance code & TI (no) & $\mathrm{BT}(\mathrm{cm})$ & $\mathrm{SD}(\mathrm{cm})$ & NGBI (no) & GY (kg/ha) \\
\hline $\mathrm{P} 1$ & 2.61cd & $0.38 \mathrm{~cd}$ & $5.27 \mathrm{~cd}$ & 1.63b-e & 78.77abc \\
\hline P2 & 2.22de & 0.36 cde & 4.92de & $1.42 \mathrm{~b}-\mathrm{e}$ & 125.96ab \\
\hline P3 & $1.61 \mathrm{e}$ & 0.326de & $4.15 \mathrm{e}$ & $1.09 \mathrm{e}$ & $55.67 \mathrm{c}$ \\
\hline P4 & $2.78 \mathrm{~cd}$ & 0.33cde & 5.08cd & 1.82a-d & 118.83ab \\
\hline P5 & 2.94bcd & $0.39 \mathrm{bc}$ & $5.77 \mathrm{bc}$ & 1.39cde & $96.60 \mathrm{abc}$ \\
\hline P6 & 2.20de & $0.31 \mathrm{e}$ & 4.74de & $1.24 \mathrm{de}$ & $55.58 c$ \\
\hline P7 & 2.46cde & $0.476 \mathrm{a}$ & 5.57cd & $1.57 \mathrm{~b}-\mathrm{e}$ & 109.19abc \\
\hline P8 & 3.11abc & $0.45 \mathrm{ab}$ & 5.49cd & $1.78 \mathrm{bcd}$ & 80.74abc \\
\hline P9 & 3.28abc & $0.47 \mathrm{a}$ & $5.83 \mathrm{bc}$ & 1.92abc & $135.78 a$ \\
\hline P10 & 2.78cd & $0.48 \mathrm{a}$ & $5.41 \mathrm{~cd}$ & 1.67b-e & $69.65 \mathrm{bc}$ \\
\hline P11 & $3.86 a$ & $0.51 \mathrm{a}$ & $6.46 a b$ & $2.04 \mathrm{ab}$ & 102.60abc \\
\hline $\mathrm{P} 12$ & $3.75 \mathrm{ab}$ & $0.51 \mathrm{a}$ & 6.70a & $2.43 a$ & 116.26ab \\
\hline Mean & 2.80 & 0.42 & 5.45 & 1.67 & 95.74 \\
\hline S.E \pm & 0.524 & 0.035 & 0.507 & 0.384 & 36.435 \\
\hline
\end{tabular}

Means followed by the same letter within a column of a treatment group are not significantly different statistically at $5 \%$ level of probability using DMRT. TI: tree incision, BT: bark thickness; SD: stem diameter; NGBI: number of gum bearing incision; GY: gum yield.

Table 3. Analysis of variance for gum yield and other morphological traits in A. senegal provenances evaluated across 3 years in Gashua.

\begin{tabular}{ccccccc}
\hline \multirow{2}{*}{ Source of variation } & df & \multicolumn{5}{c}{ Mean squares } \\
\cline { 3 - 7 } & & TI (no) & BT (cm) & SD (cm) & NGBI (no) & GY (Kg/ha) \\
\hline Year & 2 & $50.05^{* *}$ & 0.42 & $46.98^{* *}$ & $22.59^{* *}$ & $24965.12^{* *}$ \\
Rep (Year) & 6 & 0.88 & $0.01^{*}$ & 0.87 & 0.60 & 1551.87 \\
Provenance & 11 & $3.79^{* *}$ & $0.05^{* *}$ & $4.50^{* *}$ & $1.21^{* *}$ & $6635.32^{*}$ \\
Year × Provenance & 22 & 0.47 & 0.0031 & 0.20 & 0.37 & 1857.30 \\
Pooled error & 66 & 0.82 & 0.0044 & 0.77 & 0.44 & 3982.44 \\
\hline
\end{tabular}

${ }^{*},{ }^{* *}$ : Significant at $\mathrm{P}<0.05, \mathrm{P}<0.01$, respectively (F-test): TI: tree incision, BT: bark thickness; SD: stem diameter; NGBI: number of gum bearing incision; GY: gum yield.

Table 4. Descriptive statistics and genetic parameters of yield and other morphological traits of A. senegal evaluated across 3 years in Gashua.

\begin{tabular}{|c|c|c|c|c|c|c|c|c|}
\hline Traits & Range & $\sigma_{g}^{2}$ & $\sigma_{p}^{2}$ & GCV (\%) & PCV (\%) & RD (\%) & $h_{b}^{2} \quad(\%)$ & GA \\
\hline NTI & $1.61-3.86$ & 0.99 & 1.81 & 35.30 & 64.72 & 45.46 & 54.54 & 1.29 \\
\hline $\mathrm{BT}(\mathrm{cm})$ & $0.31-0.51$ & 0.02 & 0.02 & 3.66 & 4.73 & 22.64 & 77.36 & 0.19 \\
\hline $\mathrm{SD}(\mathrm{cm})$ & $4.15-6.70$ & 1.24 & 2.01 & 22.82 & 36.96 & 38.25 & 61.75 & 1.54 \\
\hline NGBI & $1.09-2.43$ & 0.26 & 0.70 & 15.35 & 41.94 & 63.40 & 36.60 & 0.54 \\
\hline GY(kg/ha) & $55.58-135.8$ & 884.3 & 4866.7 & 926.3 & 5097.6 & 81.8 & 18.2 & 22.3 \\
\hline
\end{tabular}

TI: tree incision, BT: bark thickness; SD: stem diameter; NGBI: number of gum bearing incision; GY: gum yield. 
opportunities to carry out selection for the traits. High GCV and PCV recorded for number of tree incision, stem diameter and gum yield signifying that these traits are vital for gum Arabic improvement. RD estimates of GCV in relation to respective PCV were determined to judge the extent of genetic variation in these traits. These however, suggest that the observed variations in number of gum bearing incision (63.40\%) and gum yield (81.17\%) were mostly due to environmental factors.

The estimated heritability ranges from $18.17 \%$ for gum yield (kg/ha) to $77.36 \%$ for bark thickness. Heritability estimates were earlier classified as low (0 to 30\%), moderate (30\% to 60\%) and high (above 60\%). Considering this benchmark, heritability was high for bark thickness and stem diameter indicating a satisfactory possibility of genetic improvement for these traits through selection. High heritability values for bark thickness and stem diameter have been reported [22]. Low estimation of heritability was observed for gum yield(kg/ha) whereas the number of tree incision and number of gum bearing incision showed moderate heritability values which indicated that total variability was due to genetic and environment effects. This result is similar to previous study which observed that heritability estimates for traits of most forest tree species ranged from low to moderate and largely due to dominance, epistatic and environmental effects [23].

The genetic advances (GA) at 10\% selection intensity for 5 traits are presented in Table 2. Estimate of GA for gum yield was 22.31, indicating that whenever $10 \%$ selection is made among high yielding genotypes as parents, mean yields of progenies could be improved by $22.31 \mathrm{~kg} /$ ha for the first cycle; meaning that the mean genotypic value of the new population for gum yield could be improved from 95.47 to $117.78 \mathrm{~kg} / \mathrm{ha}$. Bark thickness and number of gum bearing incision expressed low genetic advance. Thus high heritability coupled with moderate genetic advance observed for stem diameter and number of tree incision indicated that the traits were mainly controlled by additive genes and that direct selection for this trait could be effective whereas moderate or high heritability coupled with low genetic advance expressed by the remaining traits signified that the traits were largely under non additive gene control (dominance and/or epistasis) and environmental.

\subsection{Conclusion}

This study revealed that there was sufficient genetic variability in A. senegal provenances available in the germplasm that could be used for improvement in gum yield and other component attributes of the species through direct selection and hybridization.

\section{Acknowledgements}

The authors wish to express their sincere appreciation to the Executive Director of Rubber Research Institute of Nigeria for his support and the entire research staff of Gum-Arabic Sub-Station, Gashua for their cooperation during the course of the project.

\section{References}

[1] Dorthe, J. (2000) Acacia senegal (L) Willd Seed Leaflet. Danida Forest Seed Center, Denmark, No. 5, 1-2.

[2] Duke, J.A. (1981) Handbook of LEGUMES of World Economic Importance. Plenum Press, New York. http://dx.doi.org/10.1007/978-1-4684-8151-8

[3] Jamal, A. and Huntsinger, L.C. (1993) Deterioration of Sustainable Agro-Silvi-Pastoral System in the Sudan: The Gum Gardens of Kordofan. Agroforestry Systems, 23, 23-38. http://dx.doi.org/10.1007/BF00704849

[4] Awouda, H.M. (1989) Outlook for Gum Arabic: Production and Supply. Report to the Gum Arabic Company, Khartoum, $18 \mathrm{p}$.

[5] Anderson, D.M. (1993) Some Factors Influencing the Demand of Gum Arabic (Acacia senegal (L.) Willdnd Other Water-Soluble Tree Exudates. Forest Ecology and Management, 58, 1-18. http://dx.doi.org/10.1016/0378-1127(93)90127-9

[6] Leung, A.Y. (1980) Encyclopedia of Common Natural Ingredient Used in Food, Drug and Cosmetic. John Wiley and Sons, New York.

[7] Burley, J. and Wood, P.J. (1978) A Manual on Species and Provenance Research with Particular Reference to the Tropics. Tropical Forestry Papers No. 10, 34-61.

[8] FDA (2002) Baseline Survey of Gum Arabic Production in Nigeria. Federal Department of Agriculture in Collaboration with Forestry Research Institute of Nigeria and Rubber Research Institute of Nigeria, p. 126. 
[9] Ojiekpon, I.F. (2005) Proper Exploitation of Gum Arabic for Quality Control. In: Adegbehin, J.O., Ed., Training Manual on Gum Arabic Production, Proceedings of a Workshop, Gum Arabic Sub-Station, Tajuwa Village, Gashua, 18-20 October 2005, 21-30.

[10] Snedecor, G.W. and Cochran, W.G. (1987) Statistical Method. 5th Edition, Iowa State University Press, 456.

[11] Duncan, D.B. (1955) Multiple Range and Multiple F-Tests. Biometrics, 11, 1-42. http://dx.doi.org/10.2307/3001478

[12] SAS Institute (2000) SAS/STAT Guide for Personal Computer: Version 9.0. SAS Institute Inc., Cary.

[13] Johnson, H.W., Robinson, H.F. and Comstock, R.E. (1955) Estimates of Genetic and Environmental Variability in Soya Bean. Agronomy Journal, 47, 318-324. http://dx.doi.org/10.2134/agronj1955.00021962004700070009x

[14] Burton, G.N. and Devane, E.M. (1953) Estimating Heritability in Fall Fescue (Festuca arundiancea L.) from Replicated Clonal Materials. Agronomy Journal, 45, 478-481. http://dx.doi.org/10.2134/agronj1953.00021962004500100005x

[15] Nechif, O.R., Filimon, R.B. and Szilagyi, L. (2011) Genetic Variability, Heritability and Expected Genetic Advance as Indices for Yield and Yield Components Selection in Common Bean (Phaseolus vulgaris L.). Scientific Papers, UASVM Bucharest, Series A, 1222-5339.

[16] Acquaah, G. (2007) Principles of Plant Genetics and Breeding. Blackwell Publishers, Malden, 142-145.

[17] Falconer, D.S. and Mackay, T.F.C. (1996) Introduction to Quantitative Genetics. 4th Edition, Benjamin Cummings, England.

[18] Anders, R., Lars, G. and Lambart, G.O. (2003) Evaluation of Provenance Trial of Acacia senegal at Gonse Burkina Faso. Trial No. 12 in the Arid Zone Series, Danida Forest Seed Centre, Denmark and Food and Agriculture Organization, Rome., No. 5, 1- 41.

[19] Jean-Michel, H., Mama, N., Bertrand, M., Clement, F.N., Jean-Marie, T., Jean-Christophe, B., Philippe, T. and Régis, P. (2012) Gum Arabic Production in Acacia senegal Plantations in the Sudanian Zone of Cameroon: Effects of Climate, Soil, Tapping Date and Tree Provenance. Bois et Forêts Des Tropiques, No. 311, 21-33.

[20] Fakuta, N.M., Ojiekpon, I.F., Waizah, Y. and Gurin, A.S. (2010) Variability in Pod and Seed Traits on Juvenile Growth Performance of Acacia senegal (L) Willd Provenances of Sudan and Sahelian Origin of Yobe State, Nigeria. Proceedings of the 44th Annual Conference of the Agricultural Society of Nigeria, Ladoke Akintola University of Technology, Ogbomoso, 18-22 October 2010.

[21] Deshmukh, S.N., Basu, M.S. and Reddy, P.S. (1992) Genetic Variability, Character Associations and Path Coefficient Analysis of Quantitative Traits in Virginia Bunch Varieties of Ground Nut. Indian Journal of Agricultural Sciences, 56, 515-518.

[22] Fakuta, N.M., Ojiekpon, I.F., Simon, S.Y. and Gani, M. (2013) Genetical Studies for Seedling Growth Traits in Relation to Early Tapping Maturity of Gum Arabic (Acacia senegal (L) Willd). World Journal of Agricultural Sciences, 1, 248-251.

[23] Cornelius, J. (1994) Heritabilities and Additive Genetic Coefficients of Variation in Trees. Canadian Journal of Forest Research, 24, 372-379. http://dx.doi.org/10.1139/x94-050 